\title{
Pengembangan Strategi Jurnalisme Sejarah untuk Menulis Puisi Siswa Kelas X SMA
}

\author{
Amalia Juningsih $^{1}$, Wahyudi Siswanto ${ }^{1}$, Yuni Pratiwi ${ }^{1}$ \\ ${ }^{1}$ Pendidikan Bahasa Indonesia-Universitas Negeri Malang
}

\section{INFO ARTIKEL}

\section{Riwayat Artikel:}

Diterima: 21-11-2019

Disetujui: $14-09-2020$

\section{Kata kunci:}

historical journalism strategy; poetry writing; high school student; strategi jurnalisme sejarah; menulis puisi siswa SMA

\author{
Alamat Korespondensi: \\ Amalia Juningsih \\ Pendidikan Bahasa Indonesia \\ Universitas Negeri Malang \\ Jalan Semarang 5 Malang \\ E-mail: Amaliajuningsih@gmail.com
}

\begin{abstract}
The aim of the research on historical journalism strategy development is to (1) develop a product in the form of historical journalism strategy for learning to write poetry for class X high school students which is packaged in a strategy implementation guide for teachers, and (2) describe the results of the strategy product feasibility test learning journalism history for learning to write poetry in class X high school students. This developmental research was carried out by adapting procedural models from Borg and Gall. The results of the development research include three things, namely (1) product description, (2) presentation of product test results, and (3) product revision.

Abstrak: Tujuan dari penelitian pengembangan strategi jurnalisme sejarah adalah untuk (1) mengembangkan produk berupa strategi jurnalisme sejarah untuk pembelajaran menulis puisi siswa kelas X SMA yang dikemas dalam buku panduan penerapan strategi untuk guru dan (2) mendeskripsikan hasil uji kelayakan produk strategi pembelajaran jurnalisme sejarah untuk pembelajaran menulis puisi siswa kelas $\mathrm{X}$ SMA. Penelitian pengembangan ini dilakukan dengan mengadaptasi model prosedural dari Borg dan Gall. Hasil dari penelitian pengembangan meliputi tiga hal, yaitu (1) deskripsi produk, (2) penyajian data hasil uji coba produk, dan (3) revisi produk.
\end{abstract}

ABSTRAK

Strategi pembelajaran berpengaruh terhadap kelancaran proses pencapaian tujuan pembelajaran. Dalam strategi pembelajaran pemilihan konsep atau teori dasar sebagai dasar pengembangan tidak dapat dilakukan secara serta merta. (Torralba \& Doo, 2020). Pertimbangan utama di dalam memilih konsep atau teori dasar adalah dengan menetapkan tujuan pembelajaran yang ingin dicapai, setelah menetapkan tujuan pembelajaran, pengembang strategi dapat menentukan konsep untuk landasan pengembangan strategi yang mencakup teori-teori dasar dan hasil penelitian terdahulu sebagai pengalaman yang telah teruji. Pada proses pembelajaran guru perlu mengembangkan strategi yang inovatif agar siswa terlibat aktif dan suasana kelas menjadi menyenangkan. Melalui penerapan strategi pembelajaran yang tepat, guru dapat mengondisikan suasana pembelajaran menjadi nyaman, menyenangkan, serta kondusif untuk belajar. Selain itu, strategi pembelajaran yang tepat dapat memberikan stimulus positif bagi siswa untuk aktif terlibat di dalam pembelajaran.

Strategi pembelajaran adalah langkah-langkah atau prosedur belajar untuk menyampaikan materi (Neroni, Meijs, Gijselaers, Kirschner, \& de Groot, 2019). Pendapat lebih rinci dijelaskan oleh Jihad dan Haris (2013), menyatakan bahwa strategi pembelajaran merupakan pendekatan dalam mengelola kegiatan, dengan mengintegrasikan urutan kegiatan, cara mengorganisasikan materi pelajaran dan pembelajar, peralatan dan bahan serta waktu yang digunakan dalam proses pembelajaran, untuk mencapai tujuan pembelajaran yang telah ditentukan secara efektif dan efisien. Berdasarkan pendapat tersebut strategi diperlukan dalam proses pembelajaran agar tujuan penyampaian materi sesuai dengan rencana pembelajaran yang telah ditentukan.

Berdasarkan hasil pengamatan, diketahui bahwa pembelajaran menulis puisi di sekolah cenderung menggunakan prosedur dan aturan yang baku dan kurang mengarahkan siswa untuk berproses kreatif. Kreativitas dalam menulis puisi akan menghasilkan puisi yang berkualitas dan hal tersebut bergantung metode yang digunakan guru dalam mengajar. Hal tersebut sesuai dengan pernyataan (Linaberger, 2005) diperlukan metode belajar yang mengarahkan siswa untuk aktif untuk menyelesaikan tugas, dan siswa memiliki dasar untuk kreatif. Selain itu, pembelajaran menulis puisi pada penerapannya juga identik dengan imajinasi bebas dari penulis dengan mengamati berbagai fenomena di sekitar. Padahal puisi tidak semata-mata hanya ekspresi dan imajinasi penulis, namun juga dapat digunakan untuk mengungkap kembali fakta-fakta yang diwujudkan dalam bentuk imajinasi (Hasirci \& Ultav, 2012). Salah satu fakta-fakta yang dapat diwujudkan melalui penciptaan puisi adalah fakta-fakta sejarah yang terdapat berbagai fenomena peristiwa sejarah. Dalam suatu wilayah atau daerah kaya akan situs sejarah, 
maka guru dapat memanfaatkan sumber belajar yang terdapat di daerah. Situs sejarah yang dijadikan sumber belajar dapat menambah pengalaman baru bagi peserta didik selain dari sumber belajar yang biasanya telah diterapkan. Hal tersebut senada dengan pendapat (Samsudin, 2016) bahwa dengan memanfaatkan sumber belajar yang terdapat dilingkungan merupakan suatu kegiatan menyampaikan pelajaran di luar kelas yang mengajak siswa lebih dekat dengan sumber belajar yang sesungguhnya, siswa bukan hanya menerima pengetahuan dari apa yang mereka dengar, tetapi juga dari apa yang ia lihat dan ia lakukan sehingga para siswa secara langsung melibatkan semua panca indera dan aspek motorik lainnya, serta dengan memanfaatkan lingkungan sebagai sumber belajar siswa dapat menghubungkan konsep yang dipelajari dengan kondisi riil yang terjadi di lingkungan. Oleh karena itu, dikembangkan strategi jurnalisme sejarah untuk pembelajaran menulis puisi yang memanfaatkan sumber belajar yang terdapat di lingkungan sekitar.

Strategi jurnalisme sejarah dikembangkan berdasarkan tiga landasan penting yakni (1) terinspirasi dari tugas jurnalis secara umum, (2) sumber, fakta dan bukti sejarah, dan (3) proses kreatif dalam menulis puisi. Ketiga landasan tersebut diintegrasikan untuk menjadi strategi pembelajaran yakni strategi jurnalisme sejarah untuk menulis puisi yang bertemakan sejarah dengan tahapan yang cocok diterapkan dalam pembelajaran. Landasan pertama adalah tugas jurnalis secara umum dalam melaksanakan tugas sebagai peliput dan pengemas berita. Tugas jurnalis tersebut yakni mencari berita, mengolah berita dan menyunting berita (Romli, 2003) (Tebbel, 2003). Tugas jurnalis berkaitan dengan media dan hubungan dengan masyarakat, tugas tersebut dilaksanakan jurnalis dalam dunia kerja profesional (Shaw \& White, 2004). Menurut Suhandang (2004), jurnalistik adalah profesi yang menyajikan informasi dalam bentuk penerangan, penafsiran dan pengkajian mengenai kejadian atau kehidupan sehari-hari. Dari pendapat tersebut kegiatan jurnalistik yang dilaksanakan oleh jurnalis berperan aktif dalam peliputan berita mengenai kejadian atau peristiwa penting yang kemudian dikemas menarik untuk disajikan di media cetak atau elektronik. Tugas jurnalis tersebut menjadi sumber inspirasi landasan pertama untuk memperoleh data dan informasi yang akurat dengan kegiatan reportase dan wawancara dengan narasumber. Ketiga tugas jurnalis tersebut diwujudkan dalam langkahlangkah pembelajaran yakni tahap mencari berita yang difungsikan sebagai tahap mencari topik, tahap mengolah berita sebagai tahap mengolah data, dan tahap menyunting berita sebagai tahap menyunting data.

Landasan kedua, berkaitan dengan tugas jurnalis yakni tahap mencari topik sejarah berlandaskan pada landasan kedua yakni sumber, bukti dan fakta yang valid. Menurut Sjamsuddin (2007), sumber sejarah merupakan segala sesuatu yang menceritakan kegiatan manusia pada masa lalu berdasarkan fakta yang ada baik secara langsung ataupun tidak langsung. Bukti merupakan keterangan dalam bentuk laporan tertulis yang memuat fakta-fakta sejarah secara jelas. Bukti tidak tertulis dapat berupa cerita atau tradisi, sedangkan fakta sejarah adalah data yang terseleksi yang berasal dari berbagai sumber sejarah (Sulasman, 2014). Berdasarkan pendapat tersebut dapat disimpulkan bahwa baik sumber, bukti dan fakta memuat berbagai peristiwa sejarah yang berhubungan dengan kegiatan-kegiatan manusia dimasa lalu yang dapat dibuktikan kebenarannya. Berdasarkan pendapat tersebut topik sejarah yang dipilih oleh pendidik selain berdasarkan sumber, bukti dan fakta yang valid juga berdasarkan kebermanfaatan dan keefektifan belajar bagi siswa.

Landasan ketiga, yakni proses kreatif dalam menulis puisi. Puisi merupakan karangan tertulis yang terwujud dari penjelajahan pemikiran, perasaan, yang melibatkan imajinasi. Pemikiran-pemikiran dalam menulis puisi merupakan wujud eksplorasi dari berbagai peristiwa. Hal tersebut sesuai dengan pernyataan (Anat, 2017) perbedaan dalam menulis puisi berasal dari penggunaan bahasa oleh penyair yang terinspirasi dari peristiwa tertentu dan hal tersebut membuat keunikan tersendiri. Selama ini puisi identik dengan imajinasi bebas dari penyair dengan mengamati lingkungan sekitar atau peristiwa berkesan dalam hidup. Sedangkan puisi juga mempunyai peran penting dalam sarana untuk mengungkap fakta-fakta dari berbagai peristiwa sosial. Dalam mengolah fakta-fakta sejarah menjadi puisi harus melewati proses kreatif karena merupakan dasar penciptaan puisi. Puisi tidak hanya mementingkan aspek keindahan/estetika, namun pesan dan makna yang dituliskan penyair bisa tersampaikan secara tepat kepada pembaca, menulis puisi melalui proses kreatif harus bisa melampaui bidang estetika dan menyampaikan pesan kepada pembaca (Pratiwi, Maryaeni, \& Suwignyo, 2016). Dalam menulis puisi ekspresi dalam diri penulis ketika menulis merupakan hal yang subjektif dan menjadi ciri khas masing-masing penulis, tetapi hal tersebut tidak terwujud dengan baik apabila siswa tidak melewati proses kreatif. Hal tersebut senada dengan pendapat (Sulistyorini, 2010) proses kreatif tentunya diperlukan dalam menulis puisi. Proses kreatif dapat dilakukan dengan cara banyak berlatih, karena semakin sering seseorang berlatih menulis, maka ia semakin terampil, ide dan gagasannya pun semakin banyak. Siswa dapat mengungkapkan ide atau pikirannya melalui proses kreatif tersebut dalam bentuk puisi. Kreativitas dalam menulis puisi melalui tahap proses berpikir kreatif yang menuangkan gagasan-gagasan dari kegiatan membaca dan mengamati ke dalam bentuk tulisan. Gagasan-gagasan dapat diperoleh dari hasil pengamatan dan pengetahuan siswa dari berbagai sumber. Pada saat menuangkan gagasan-gagasan tersebut, siswa tentu mendayagunakan kemampuan berbahasa sehingga tercipta karya sastra. Kreativitas dalam berbahasa dianggap menjadi bagian dari sifat manusia yang unik, bersama dengan kemampuan untuk menggunakan kompleks sistem semiotik yakni bahasa yang bermakna (Rosenhan \& Galloway, 2019). Hal tersebut senada dengan pendapat (Hasanah, 2014) kreativitas penyair mendorong dilaksanakannya pembaruan (inovasi) sekalipun dalam hal-hal tertentu tidak meninggalkan konvensi yang lazim dalam puisi.

Dalam menulis puisi, unsur kebahasaan meliputi citraan, majas, dan harmonisasi bunyi merupakan unsur yang penting diterapkan agar puisi yang dihasilkan memiliki variasi yang berbeda dengan bahasa sehari-hari dan memiliki keindahan serta menarik untuk dibaca. Hal tersebut merupakan simbol dalam puisi modern (Pedersen, 2015). Proses kreatif merupakan dasar penciptaan puisi. Di dalam proses kreatif, terdapat hal-hal atau aktivitas-aktivitas yang akan dilalui untuk menghasilkan karya 
yang lebih baik dan berkualitas. Menurut Roekhan (1991), mengungkapkan tahapan-tahapan menulis kreatif yang meliputi (1) pemunculan ide, (2) pengembangan ide, (3) pelahiran ide, dan (4) penyempurnaan ide. Pada tahap pemunculan ide, ide muncul di waktu dan tempat yang beragam. Ide perlu segera dicatat begitu ide tersebut melintas agar penyair dapat mengolah ide dengan utuh. Tahap pengembangan, pemunculan ide biasanya tidak lengkap. Oleh karena itu, ide perlu diolah dan dimatangkan sebelum ditulis menjadi karya sastra. Pematangan ide dapat dilakukan dengan melakukan pengamatan, perincian, atau perenungan. Kegiatan pengamatan dapat dilakukan dengan mengamati dengan cermat dan rinci mengenai suatu objek, suasana, atau peristiwa tertentu. Tahap pelahiran ide, ide yang dikembangkan melalui pengamatan yang cermat terhadap objek, suasana, atau peristiwa tertentu. Selain itu, penyair juga perlu melatih kemampuan menulisnya dengan ajeg dan tekun untuk mengatasi hambatan yang berupa ketidaklancaran dalam menulis karya sastra. Tahap penyempurnaan ide, ide yang dimiliki penyair tidak datang dengan utuh dan sempurna. Oleh karena itu, biasanya ide perlu diubah, ditambah, bahkan dikurangi. Penyempurnaan ini dapat dilakukan secara langsung setelah membaca ulang karya sastra yang ditulis atau menggunakan jeda waktu setelah selesai menulis.

Tahapan-tahapan lain dijelaskan oleh Endraswara (2003), mengemukakan empat tahap proses kreatif yang meliputi (1) tahap penggalian, (2) tahap perenungan, (3) tahap koreksi, dan (4) tahap introspeksi. Pada tahap penggalian, seorang penyair harus peka dalam menangkap berbagai fenomena untuk kemudian diasosiasikan dengan visi diri dan merenungkannya untuk beberapa saat agar memperoleh gambaran yang utuh tentang ide yang akan dituliskan. Pada tahap perenungan, penyair tersebut mulai menuliskan karyanya berdasarkan idenya. Pada tahap ini, semua perasaan, pikiran, dan kemauan dicurahkan ke dalam karya yang ditulis. Pada tahap ketiga, yaitu tahap koreksi, penyair melakukan penyuntingan dan perbaikan sebelum karya dinikmati oleh pembaca. Pada tahap terakhir, yaitu tahap instrospeksi merupakan tahap dimana karya akan dinikmati dan dinilai untuk pembaca. Pada tahap inilah, terjadi kritik oleh pembaca terhadap karya sehingga penyair dapat melakukan penyempurnaan kembali demi meningkatnya kualitas karya.

Pendapat lebih rinci dijelaskan oleh Widijanto merumuskan lima tahap di dalam proses kreatif menulis puisi dengan mengadaptasi proses kreatif Miller. Menurut Widijanto (2014), kelima tahap tersebut meliputi (1) tahap persiapan, (2) tahap inspirasi, (3) tahap inkubasi, (4) tahap penulisan, dan (5) tahap revisi. Pada tahap persiapan, penyair telah menyadari gagasan apa yang ditulisnya dan bentuk atau wujud penulisan gagasan tersebut. Pada tahap inspirasi, gagasan yang telah muncul disimpan, dipikirkan kembali untuk mematangkan gagasan tersebut, dan ditunggu waktu yang tepat untuk menuliskannya. Pada tahap inkubasi, gagasan dimatangkan kembali menjadi konsep yang utuh dan segera ditulis. Pada tahap penulisan, konsep yang telah dituliskan secara kasar pada tahap inkubasi segera dituangkan secara utuh, tetapi tetap dalam bentuk draf atau rancangan kasar. Pada tahap revisi, penyair perlu membuat jarak sejenak antara dirinya dengan karya yang ditulisnya. Selanjutnya, penyair dapat memperbaiki karyanya dengan memberikan penambahan, pengurangan, atau pengubahan. Proses kreatif yang terjadi antara satu penyair dengan penyair lainnya tentu tidak sama. Akan tetapi, setidaknya terdapat empat tahap proses kreatif yang dialami oleh penyair secara umum. Kelima tahap tersebut, meliputi (1) tahap menggali dan memunculkan ide, (2) tahap menentukan kata kunci, (3) tahap memilih diksi yang tepat, (4) tahap mengembangkan diksi, dan (5) tahap koreksi dan revisi.

Ketiga landasan tersebut dipadukan hingga membentuk sebuah konsep strategi jurnalisme sejarah yang tertuang sebagai rangkaian kegiatan belajar bagi siswa pada pembelajaran menulis puisi dengan tema sejarah. Dalam menulis karya sastra dengan latar belakang peristiwa sejarah harus didasari dengan riset yang mendalam agar tidak hanya sekadar imajinasi dan fiksi belaka (Khakim, 2016). Berdasarkan hal tersebut, pada kegiatan pembelajaran siswa diposisikan menjadi jurnalis dalam mengumpulkan informasi berupa fakta-fakta yang berkaitan dengan topik sejarah.

Secara umum, tujuan penelitian pengembangan ini adalah untuk menghasilkan produk berupa strategi jurnalisme sejarah untuk pembelajaran menulis puisi yang dikemas dalam buku panduan bagi guru. Tujuan penelitian pengembangan (1) mengembangkan produk berupa strategi jurnalisme sejarah untuk pembelajaran menulis puisi siswa kelas X SMA yang dikemas dalam buku panduan penerapan strategi untuk guru dan (2) mendeskripsikan hasil uji kelayakan produk strategi pembelajaran jurnalisme sejarah untuk pembelajaran menulis puisi siswa kelas X SMA.

\section{METODE}

Penelitian pengembangan ini dilakukan dengan mengadaptasi model prosedural dari Borg dan Gall. Pada model pengembangan yang asli, terdapat sepuluh langkah pengembangan yang meliputi (1) penelitian dan pengumpulan informasi awal, (2) perencanaan (3) pengembangan format produk awal, (4) uji coba awal, (5) revisi produk, (6) uji coba lapangan, (7) revisi produk, (8) uji lapangan, (9) revisi produk akhir, serta (10) desiminasi dan implementasi ( Borg dan Gall, 2003:570-571). Kesepuluh langkah tersebut diadaptasi menjadi tujuh pengembangan model pembelajaran jurnalisme sejarah. Ketujuh tahap tersebut adalah (1) studi pendahuluan, (2) perencanaan, (3) pengembangan draft produk, (4) uji validasi, (5) revisi produk awal, (6) uji lapangan terbatas, dan (7) penyempurnaan produk akhir. Penerapan strategi jurnalisme sejarah dilaksanakan pada tahap keenam, yaitu uji coba lapangan terbatas. Pada uji coba lapangan terbatas, siswa akan mengikuti kegiatan belajar meliputi tiga tahap, yaitu tahap mencari topik, mengolah data, dan menyunting data.

Tahap pertama yakni mencari topik, aktivitas belajar yang dilakukan siswa, meliputi (1) siswa memahami puisi sejarah dan unsur-unsur pembentuknya melalui penjelasan guru, (2) siswa melihat tayangan video inspiratif dan puisi yang berkaitan dengan sejarah, (3) siswa memahami dan memaknai pentingnya mempelajari peristiwa sejarah melalui diskusi klasikal, (4) siswa mendapatkan topik dari guru mengenai suatu sejarah tertentu, (5) siswa memahami tugas jurnalis melalui penjelasan guru, 
(6) siswa menerapkan tugas jurnalis dengan menulis pertanyaan memuat unsur $5 \mathrm{~W}+1 \mathrm{H}$ berkaitan dengan topik sejarah, (7) siswa melakukan kegiatan wawancara dengan narasumber untuk mendapatkan fakta sejarah, dan (8) siswa mencatat pokokpokok hasil wawancara. Pada praktik jurnalis, siswa diposisikan menjadi jurnalis dengan mengunjungi situs sejarah dan menerapkan kegiatan wawancara dengan narasumber. Situs sejarah digunakan sebagai sumber belajar peserta didik, dengan menerapkan sumber belajar tersebut siswa akan mendapatkan pengalaman dan pengetahuan baru. Guru memiliki peran sebagai penghubung, yakni mampu menghubungkan anak didik dengan sumber-sumber belajar yang beragam baik didalam maupun diluar sekolah (Rahman, 2017). Tahap kedua yakni mengolah data, aktivitas belajar pada dilakukan oleh siswa meliputi, (1) siswa mengembangkan pokok-pokok wawancara dalam sebuah teks narasi, (2) siswa menulis teks narasi secara runtut dan rinci yang dimulai dari pendahuluan yakni menulis tentang sejarah apa yang ditelusuri, lokasi sejarah, dan akses menuju situs sejarah, (3) siswa menulis inti teks narasi sejarah dengan mengulas ciri khas yang terdapat pada suatu sejarah dan peradabannya, (4) siswa menulis akhir dari teks narasi dengan menuliskan pesan moral dari peristiwa suatu sejarah dan relevansi dengan kehidupan saat ini. Tahap ketiga yakni menyunting data, aktivitas belajar yang dilakukan oleh siswa meliputi, (1) siswa memilah teks narasi berdasarkan alur pengisahan, (2) siswa menentukan kata kunci teks narasi berdasarkan alur pengisahan. Alur pengisahan terdapat dua yakni alur keseluruhan dan alur sebagian/potongan alur, (3) siswa mendeskripsikan hasil refleksi dari pilihan alur, (4) siswa mengimajinasikan hasil deskripsi refleksi dalam bentuk sebuah kesatuan yang bersifat simbolis, (5) siswa mengumpulkan pilihan kata atau diksi dari hasil pengimajinasian, (6) siswa merangkai larik-larik puisi dengan menggunakan diksi yang telah dikumpulkan, (7) siswa menulis larik-larik yang telah dibuat ke dalam susunan bait sehingga diperoleh draf puisi yang utuh, (8) siswa membaca kembali draf puisi yang telah ditulis sebelumnya, (9) siswa mengubah, menghilangkan bagian-bagian yang tidak sesuai, atau menambahkan pilihan kata yang lebih puitis dengan memperkaya aspek citraan, majas dan harmonisasi bunyi.

Desain uji coba dalam penelitian pengembangan ini menggunakan desain deskriptif. Dengan menggunakan desain deskriptif, kekurangan dan kelebihan produk digambarkan secara objektif sehingga perbaikan produk dapat diperoleh secara lengkap melalui uji dari para ahli dan praktisi. Uji produk pengembangan strategi pembelajaran jurnalisme sejarah dilakukan melalui dua langkah, yaitu (1) uji kelayakan oleh ahli dan praktisi, dan (2) uji coba lapangan terbatas. Uji kelayakan oleh ahli dan praktisi melibatkan ahli puisi, ahli pembelajaran menulis puisi, dan praktisi bahasa Indonesia pada jenjang kelas X SMA.

Tabel 1. Validasi Kelayakan oleh Ahli dan Praktisi

\begin{tabular}{|c|c|c|c|}
\hline No. & Tahap & Data & Sumber Data \\
\hline 1. & $\begin{array}{l}\text { Validasi ahli } \\
\text { pembelajaran }\end{array}$ & $\begin{array}{l}\text { a. Skor hasil penilaian ahli model/strategi } \\
\text { b. Catatan secara lisan dan tertulis }\end{array}$ & $\begin{array}{l}\text { Instrumen penilaian ahli } \\
\text { model/strategi }\end{array}$ \\
\hline 2. & $\begin{array}{l}\text { Validasi ahli } \\
\text { puisi }\end{array}$ & $\begin{array}{ll}\text { a. } & \text { Skor hasil penilaian ahli materi } \\
\text { b. } & \text { Catatan secara lisan dan tulis }\end{array}$ & $\begin{array}{l}\text { Instrumen penilaian ahli } \\
\text { materi }\end{array}$ \\
\hline 3. & Validasi praktisi & $\begin{array}{l}\text { a. Skor hasil penilaian praktisi pembelajaran bahasa Indonesia } \\
\text { b. Catatan secara lisan dan tulis }\end{array}$ & Intrumen penilaian praktisi \\
\hline & Uji coba & $\begin{array}{ll}\text { a. } & \text { Keberterimaan strategi } \\
\text { b. } & \text { Skor menulis puisi }\end{array}$ & $\begin{array}{l}\text { a. Angket } \\
\text { b. Rubrik penilaian } \\
\text { menulis puisi }\end{array}$ \\
\hline
\end{tabular}

Pada uji coba lapangan terbatas, subjek uji adalah siswa dalam kelompok terbatas, yaitu siswa kelas X bahasa MA Ma'arif NU Sidomukti yang berjumlah 34 orang. Dalam hal ini instrumen yang digunakan untuk mengumpulkan data adalah angket. Angket tersebut disebarkan dan diisi oleh siswa yang menjadi subjek uji. Data yang diperoleh dari penelitian pengembangan strategi pembelajaran jurnalisme sejarah meliputi dua jenis data. Kedua jenis data tersebut, yaitu (1) data verbal dan (2) data numerik. Pertama, data verbal yang dihimpun berupa data verbal tertulis dan data verbal lisan. Data verbal tertulis adalah data yang berupa catatan, komentar, kritik, saran pada lembar angket para subjek uji, serta berupa hasil puisi dengan tema sejarah karya siswa yang dihimpun dari uji coba lapangan terbatas. Data verbal lisan merupakan informasi yang diperoleh ketika wawancara dan masukan-masukan secara lisan dari ahli maupun praktisi. Data verbal lisan tersebut kemudian ditranskrip ke dalam bentuk tertulis. Kedua, data numerik adalah data berupa skor yang diperoleh dari angket yang diisi oleh para subjek uji. Skor tersebut dibedakan menjadi dua, yaitu (1) skor yang didapat dari hasil angket oleh subjek ahli dan praktisi dan (2) skor yang didapat dari hasil angket oleh subjek uji lapangan siswa.

Pada tahap studi pendahuluan, peneliti melakukan wawancara dengan guru dan memberikan pertanyaan-pertanyaan secara spontan dan bebas. Akan tetapi, tetap berpedoman pada rancangan pertanyaan yang mengarah pada penggalian informasi tentang pelaksanaan pembelajaran menulis puisi. Wawancara juga dilaksanakan pada tahapan uji kelayakan oleh ahli dan praktisi. Dalam tahap uji kelayakan, pertanyaan yang diajukan juga bersifat bebas dan spontan, tetapi mengarah pada penggalian informasi mengenai komentar, kritik, saran dan masukan untuk memperbaiki produk. Angket yang ditujukan pada siswa pada uji lapangan terbatas, isi angket meliputi pertanyaan-pertanyaan yang berhubungan dengan tingkat keterbantuan serta minat siswa dalam pembelajaran puisi setelah penerapan strategi jurnalisme sejarah. Berikut merupakan aspek dan indikator pada angket siswa. 
Teknik analisis data yang digunakan dalam penelitian pengembangan adalah teknik analisis kualitatif dan teknik analisis kuantitatif. Teknik analisis kualitatif digunakan untuk menganalisis data verbal dari wawancara informal dan catatan tertulis berupa komentar, saran, dan masukan pada angket, baik angket uji kelayakan oleh ahli dan praktisi maupun angket uji lapangan terbatas. Hal tersebut sesuai dengan pernyataan (Orion \& Hofstein, 1994) teknik analisis kualitatif digunakan untuk analisis observasi, transkripsi wawancara, rekaman video, dan laporan guru dari masing-masing kelas dibaca dan dianalisis secara terpisah oleh peneliti. Langkah-langkah yang dilakukan untuk melaksanakan analisis kualitatif meliputi empat aktivitas, yaitu (1) mengumpulkan data verbal tertulis dari angket uji dan lembar observasi serta data verbal lisan dari hasil wawancara kepada ahli dan praktisi yang dihimpun selama uji kelayakan, (2) mentranskrip data verbal lisan yang didapat dari wawancara kepada ahli dan praktisi pada uji kelayakan, (3) mengelompokkan data verbal tulis dan hasil transkip verbal lisan ke dalam kelompok kriteria yang sesuai, dan (4) menganalisis data dan merumuskan simpulan berdasarkan kelompok data untuk menyimpulkan tindak lanjut terhadap produk strategi yang dikembangkan. Teknik analisis kuantitatif digunakan untuk menganalisis data numerik. Data numerik tersebut berupa skor yang diperoleh dari angket, baik angket uji kelayakan oleh ahli dan praktisi maupun angket uji lapangan terbatas yang diisi oleh siswa.

Analisis data validasi produk diperoleh untuk mengetahui tingkat kevalidan strategi dari instrumen yang telah memenuhi kriteria. Setiap aspek validasi menggunakan skala linkert. Setelah data dikumpulkan selanjutnya dianalisis menggunakan rumus sebagai berikut.

\section{Rumus pengolahan data per butir$$
\mathrm{P}=\frac{\mathrm{x} X 100 \%}{\mathrm{xi}}
$$

\section{Keterangan}

P $\quad$ : Presentasi hasil subjek uji coba

$\sum \mathrm{x} \quad$ : Total jawaban responden dalam satu butir

$\sum x i \quad:$ Jumlah jawaban ideal dalam satu butir

$100 \%$ : Konstanta

$\mathrm{X} \quad$ : Jawaban skor oleh subjek

$\mathrm{Xi} \quad$ : Nilai ideal dalam satu butir

$100 \%$ : Konstanta

Penghitungan yang dilakukan pada seluruh data numerik di masing-masing angket subjek uji akan menghasilkan persentase. Selanjutnya, persentase yang diperoleh tersebut dikelompokkan berdasarkan kriteria tertentu untuk mengetahui tingkat kelayakan penerapan produk. Kriteria kelayakan berdasarkan persentase hasil uji dikelompokkan sebagaimana ditunjukkan pada tabel 2.

Tabel 2. Persentase Kriteria Kelayakan Produk (Arikunto, 2009)

\begin{tabular}{cclll}
\hline \multicolumn{3}{c}{ Hasil Uji } & \multicolumn{1}{c}{ Tindak Lanjut } \\
\cline { 1 - 3 } Kategori Skor & Persentase & Kualifikasi & \\
\cline { 2 - 3 } 1. & $85-100 \%$ & Sangat layak & Implementasi \\
2. & $75-84 \%$ & Layak & Implementasi dengan sedikit revisi \\
3. & $55-74 \%$ & Cukup Layak & Revisi sesuai catatan ahli dan praktisi \\
4. & $<55 \%$ & Kurang Layak & Revisi dengan pengubahan \\
\hline
\end{tabular}

Keterangan:

a. Apabila kelayakan produk yang diuji mencapai tingkat persentase $85 \%$ sampai dengan $100 \%$, produk tersebut dapat diimplementasikan secara langsung tanpa ada revisi.

b. Apabila produk yang diuji kelayakan mencapai tingkat persentase $75 \%$ sampai dengan $84 \%$ produk tersebut dapat diimplementasikan dengan melakukan sedikit revisi.

c. Apabila produk yang diuji kelayakan mencapai tingkat persentase $55 \%$ sampai dengan $74 \%$ produk tersebut harus direvisi sesuai dengan catatan ahli dan praktisi terlebih dahulu.

d. Apabila produk yang diuji kelayakan mencapai tingkat persentase $<55 \%$ produk tersebut harus direvisi dengan melakukan pengubahan pada isi panduan penggunaan strategi.

Produk diuji efektivitasnya untuk melihat kebergunaan produk dalam meningkatkan kemampuan siswa dalam menulis puisi. Uji efektivitas produk dimaksudkan untuk memperoleh informasi tentang efektif tidaknya produk pengembangan bila diterapkan dalam proses pembelajaran di lapangan. Uji efektivitas produk dilakukan dengan melihat perbedaan skor prestasi 
siswa pada kompetensi menulis sebelum diberikan perlakuan dan skor prestasi siswa pada kompetensi menulis setelah diberikan perlakukan. Desain penelitian ini menggunakan one-group pretest-posttest design dengan metode yang digunakan dalam uji keefektifan yakni uji t satu sampel (One sample t test). Berikut desain penelitian menggunakan rumus Sugiyono (2013).

\title{
$01 \times 02$
}

\author{
Keterangan: \\ $\mathrm{O} 1=$ Nilai Pretest (sebelum diberi perlakuan) \\ $\mathrm{X}=$ Strategi Jurnalisme Sejarah \\ $\mathrm{O} 2=$ Nilai Posttest $($ setelah diberi perlakuan)
}

\section{HASIL}

Hasil penelitian pengembangan strategi jurnalisme sejarah terdiri atas tiga paparan. Ketiga paparan tersebut, meliputi (1) deskripsi produk, (2) penyajian data hasil uji coba produk, dan (3) revisi produk. Berikut adalah uraian untuk ketiga paparan hasil tersebut.

\section{Deskripsi Produk}

Strategi jurnalisme sejarah adalah strategi pembelajaran yang dikembangkan dan dirancang untuk kompetensi dasar menulis puisi dengan memerhatikan bait, larik, rima, irama, imaji, dan isi. Kompetensi tersebut berada pada jenjang kelas X SMA/MA. Strategi pembelajaran jurnalisme sejarah berfokus pada puisi dengan tema sejarah sebagai hasil belajar dan berorientasi pada aktivitas belajar siswa yang diposisikan menjadi jurnalis dengan praktik reportase dan wawancara. Tujuan dari kegiatan tersebut yakni untuk memperoleh data dan informasi yang akurat. Oleh karena itu, sumber ide penulisan puisi tema sejarah dalam strategi pembelajaran tersebut berasal dari topik sejarah yang memiliki sumber,bukti dan fakta yang valid. Karena menulis puisi dengan tema sejarah tidak sekadar hasil imajinatif, namun berperan penting dalam mengungkap kembali faktafakta. Spesifikasi produk strategi jurnalisme sejarah dirumuskan berdasarkan landasan konseptual pengembangan strategi serta langkah-langkah pelaksanaannya. Pada kerangka konseptual, spesifikasi yang dipaparkan meliputi teori-teori yang menjadi dasar pengembangan strategi jurnalisme sejarah. Pada langkah-langkah strategi, spesifikasi yang dipaparkan adalah langkahlangkah mengolah fakta-fakta sejarah menjadi puisi sejarah dari setiap tahap yang ada di dalam strategi yang dikembangkan.

Sebagai sebuah strategi pembelajaran yang dirancang secara lengkap, strategi pembelajaran menulis puisi dilengkapi dengan materi ajar dan media pembelajaran. Pertama, materi ajar. Materi ajar yang tercakup di dalam strategi jurnalisme sejarah meliputi (1) pengenalan puisi sejarah dan (2) unsur-unsur pembangun puisi. Materi pengenalan terhadap puisi sejarah mencakup pengertian tentang hakikat puisi sejarah dan contoh-contoh puisi sejarah karya penyair, yaitu (a) puisi sejarah yang bersumber dari pengalaman penyair yang terlibat dalam peristiwa sejarah, (b) puisi sejarah yang bersumber dari jejak perjuangan suatu bangsa dimasa lalu, dan (c) puisi sejarah yang bersumber dari pengamatan penyair terhadap peristiwa bersejarah yang telah terjadi dan menimbulkan kesan mendalam. Materi contoh puisi dilengkapi dengan pemaknaan puisi sebagai analisis peristiwa sejarah dimasa lalu yang tertuang dalam puisi-puisi sejarah. Materi ajar kedua adalah unsur-unsur pembangun puisi yang meliputi (a) tema, (b) diksi, (c) citraan atau imaji, (d) majas, dan (e) harmonisasi bunyi. Pemaparan materi unsur-unsur pembangun puisi terdapat contoh proses sehingga lebih rinci.

Kedua, media pembelajaran. Media pembelajaran yang digunakan dalam strategi jurnalisme sejarah meliputi (a) media audio-visual berupa video dokumenter peristiwa sejarah dan (b) contoh puisi-puisi sejarah. Media pembelajaran yang pertama adalah media audio-visual berupa video dokumenter. Media tersebut dimanfaatkan sebagai stimulator penggalian pemahaman mengenai suatu peristiwa sejarah. Selain itu, siswa dapat mengidentifikasi pengetahuan tentang peristiwa penting dibalik suatu sejarah, tokoh-tokoh yang terlibat dan manfaat dari memaknai dan mempelajari sejarah bagi generasi muda. Media pembelajaran kedua adalah audio-visual berupa contoh pembacaan (a) puisi karya penyair ternama Indonesia tentang peristiwa sejarah perjuangan pahlawan kemerdekaan bangsa Indonesia yang telah gugur (b) puisi karya penyair tentang suatu sejarah daerah, dan (c) puisi sejarah karya peneliti. Puisi pertama yakni karya penyair Indonesia yang dimanfaatkan sebagai stimulus siswa dalam mengidentifikasi dan memaknai peristiwa sejarah kemerdekaan Indonesia dalam karya sastra. Puisi kedua yakni dimanfaatkan sebagai stimulus pengetahuan siswa mengenai peristiwa sejarah yang terdapat disuatu daerah dengan keunikan dan ciri khas tersendiri. Puisi tersebut adalah salah satu contoh puisi yang diambil dari sebuah antologi puisi. Sementara itu, pemanfaatan contoh puisi karya peneliti diintegrasikan kedalam materi ajar yang diarahkan pada proses penulisan puisi.

Produk pengembangan strategi jurnalisme sejarah diwujudkan dalam bentuk buku panduan penerapan strategi yang ditujukan untuk guru. Buku panduan tersebut diberi judul Model Strategi Jurnalisme Sejarah untuk Pembelajaran Menulis Puisi Siswa Kelas X. Buku Model Strategi Jurnalisme Sejarah untuk Pembelajaran Menulis Puisi Siswa Kelas X terdiri dari lima bab. Bab pertama membahas tentang konsep dasar strategi jurnalisme sejarah yang meliputi enam hal. Keenam hal tersebut adalah (1) landasan strategi jurnalisme sejarah, (2) strategi jurnalisme sejarah, (3) karakteristik jurnalisme sejarah, (4) keunggulan dan kelemahan strategi jurnalisme sejarah, (5) konsep dasar puisi sejarah, dan (6) mengenal puisi sejarah. Bab kedua membahas tentang tahapan strategi jurnalisme sejarah yang meliputi lima hal. Kelima hal tersebut adalah (1) tahap 
mencari topik, (2) tahap mengolah data, (3) tahap menyunting data, (4) alur strategi jurnalisme sejarah, dan (5) tabel tahapan strategi jurnalisme sejarah. Bab ketiga membahas tentang implementasi strategi jurnalisme sejarah dalam menulis puisi yang meliputi tiga hal. Ketiga hal tersebut adalah (1) tahap mencari topik, (2) tahap mengolah data, (3) tahap menyunting data. Bab keempat membahas tentang perangkat pembelajaran yang meliputi dua hal. Kedua hal tersebut adalah (1) rencana pelaksanaan pembalajaran dan (2) rubrik penilaian. Bab kelima membahas tentang penutup dari buku panduan, yakni (1) kesimpulan dan (2) saran.

\section{Penyajian Data Hasil Uji Coba Produk}

Penelitian pengembangan ini menghasilkan produk model strategi pembelajaran yang dikemas dalam bentuk buku panduan penerapan strategi jurnalisme sejaran untuk pembelajaran menulis puisi. Buku panduan tersebut melewati dua tahap uji, yaitu (1) uji kelayakan oleh ahli dan praktisi serta (2) uji lapangan terbatas. Penyajian dari kedua tahap uji tersebut terdiri dari empat jenis data yang meliputi (1) kelayakan konsep strategi jurnalisme sejarah, (2) kelayakan langkah-langkah strategi jurnalisme sejarah dalam pembelajaran menulis puisi, (3) kelayakan strategi jurnalisme sejarah terhadap tingkat pemahaman dan kebutuhan siswa, (4) deskripsi hasil implementasi strategi jurnalisme sejarah dalam pembelajaran menulis puisi, dan (5) Kelayakan uji efektifitas data. Keempat data uji kelayakan tersebut disajikan sebagai data numerik yang dihitung berdasarkan skor kelayakan dari hasil angket uji.

\section{Kelayakan Konsep Strategi Jurnalisme Sejarah}

Kelayakan konsep strategi jurnalisme sejarah terdapat tiga aspek penilaian. Aspek pertama yakni konsep strategi jurnalisme sejarah pada penilaian tahap pertama memperoleh persentase sebesar 70\%. Dengan demikian, konsep strategi jurnalisme sejarah melewati tahap revisi sesuai dengan catatan ahli pembelajaran puisi dan ahli puisi. Terdapat komentar yang seragam, dari ahli pembelajaran puisi maupun ahli puisi yaitu terkait dengan penataan substansi strategi jurnalisme sejarah pada produk panduan penerapan strategi. Komentar dari ahli pembelajaran puisi bahwa penataan sajian teori, langkah-langkah pembelajaran, kecermatan dan keefektifan bahasa, pemberian judul atau nama yang menarik terkait dengan tahapan pembelajaran, pengembangan tahapan pembelajaran menjadi flowchart diagram alir dan kesistematisan latihan. Sementara itu, komentar dari ahli puisi adalah adalah sajian isi buku panduan, meliputi teori, langkah-langkah strategi, instruksi atau penugasan perlu ditata ulang agar sistematikanya lebih jelas. Pada penilaian tahap kedua dilakukan setelah melewati tahap revisi sesuai dengan catatan ahli pembelajaran puisi dan ahli puisi. Subaspek konsep strategi jurnalisme sejarah memperoleh persentase sebesar 90\%. Dengan demikian, konsep dasar strategi layak diimplementasikan. Terdapat komentar dari ahli pembelajaran puisi yakni berkaitan dengan kecermatan penggunaan bahasa dalam buku panduan dan kerapihan pengetikan. Selain itu langkah-langkah pembelajaran masih perlu disempurnakan agar sistematis.

Aspek kedua yang dinilai adalah relevansi strategi jurnalisme sejarah dengan kurikulum. Subaspek pada penilaian pertama tersebut mendapatkan persentase sebesar $80 \%$ dari ahli pembelajaran. Dengan demikian, subaspek tersebut layak diimplementasikan dengan sedikit revisi. Komentar dari ahli pembelajaran menyatakan bahwa penyajian materi pembelajaran perlu ditambah dan disesuaikan dengan kurikulum. Pada penilaian tahap kedua mendapatkan persentase sebesar $90 \%$ dari ahli pembelajaran dan praktisi. Dengan demikian, subaspek tersebut layak diimplementasikan. Kelayakan tersebut didukung dengan pendapat dari praktisi yang menyatakan bahwa (1) pengembangan teori, materi, dan konsep strategi jurnalisme sejarah sudah sesuai dengan kurikulum, serta (2) strategi yang dikembangkan menarik karena sesuai dengan kearifan lokal masyarakat dengan pembelajaran yang tidak hanya di dalam kelas, namun juga di luar kelas dengan praktik jurnalis ke situs sejarah yang lokasinya dekat dengan sekolah.

Aspek ketiga adalah kesesuaian strategi jurnalisme sejarah dengan prinsip menulis puisi. Subaspek pada penilaian pertama tersebut mendapatkan persentase sebesar 80\%. Dengan demikian, subaspek tersebut layak diimplementasikan dengan sedikit revisi. Pada subaspek penilaian kedua mendapatkan persentase sebesar 86,7\%. Dengan demikian, kesesuaian strategi jurnalisme sejarah dengan prinsip menulis puisi sudah layak diimplementasikan tanpa revisi karena skornya berada pada rentang $85 \%$ hingga $100 \%$.

\section{Kelayakan Langkah-Langkah Strategi Jurnalisme Sejarah dalam Pembelajaran Menulis Puisi}

Kelayakan langkah-langkah strategi terdapat empat aspek penilaian. Aspek penilaian pertama yakni relevansi strategi dengan pelaksanaan pembelajaran menulis puisi pada penilaian tahap pertama memperoleh persentase kelayakan sebesar $76 \%$ dari ahli pembelajaran menulis puisi. Dengan demikian, subaspek tersebut layak diimplementasikan dengan sedikit revisi karena berada pada rentang persentase $75 \%$ hingga $84 \%$. Terdapat saran dari ahli pembelajaran puisi untuk mengoperasionalkan tahapan tugas jurnalis dalam strategi dan menyesuaikan materi puisi dengan tema sejarah. Pada penilaian tahap kedua memperoleh persentase kelayakan sebanyak 94\% dari ahli pembelajaran puisi dan praktisi. Dengan demikian, subaspek tersebut layak diimplementasikan tanpa revisi karena berada pada rentang $85 \%$ hingga $100 \%$. 
Aspek kedua yang dinilai adalah efektivitas dan efisiensi strategi jurnalisme sejarah. Subaspek pada penilaian tahap kedua tersebut memperoleh persentase kelayakan sebesar $88 \%$ dari praktisi. Dengan demikian, subaspek tersebut layak diimplementasikan. Hal tersebut dikarenakan persentase kelayakan subaspek efektivitas dan efesiensi strategi berada pada rentang $85 \%$ hingga $100 \%$ di mana status tindak lanjutnya adalah implementasi.

Aspek ketiga yang dinilai adalah penyajian langkah-langkah kegitan di dalam strategi jurnalisme sejarah. Pada subaspek penilaian tahap kedua tersebut mendapat persentase kelayakan sebesar $86,7 \%$ dari praktisi. Oleh karena itu, status tindak lanjut subaspek tersebut adalah implementasi. Hal tersebut didukung dengan komentar dari praktisi yang menyatakan bahwa tahapan proses belajar dalam strategi menarik karena pembelajaran tidak hanya di dalam kelas namun juga diluar kelas dan strategi jurnalisme sejarah dalam menulis puisi dengan tema sejarah tepat karena dapat mengangkat kearifan lokal daerah setempat.

Aspek keempat adalah relevansi strategi jurnalisme sejarah dengan proses menulis puisi. Subaspek penilaian tahap pertama mendapat persentase kelayakan sebesar $78 \%$ dari ahli puisi. Dengan demikian, status tindak lanjutnya adalah implementasi dengan sedikit revisi. Terkait dengan hal tersebut terdapat komentar dari ahli puisi yang menyatakan bahwa pada penataan langkah strategi tahap penulisan puisi perlu ditata ulang agar tidak terkesan dualisme yakni ditujukan untuk guru atau siswa. Pada subaspek tahap penilaian kedua mendapat persentase kelayakan sebesar 94\% dari ahli puisi dan praktisi. Dengan demikian, status tindak lanjutnya adalah implementasi karena berada pada rentang $85 \%$ hingga $100 \%$.

\section{Kelayakan Strategi Jurnalisme Sejarah Terhadap Tingkat Pemahaman dan Kebutuhan Siswa}

Kelayakan strategi jurnalisme terhadap tingkat pemahaman kebutuhan siswa terdapat dua aspek penilaian. Aspek pertama yang dinilai adalah kesesuaian strategi jurnalisme sejarah dengan tingkat pemahaman dan kebutuhan siswa mendapatkan persentase sebesar $76 \%$ pada penilaian tahap pertama. Dengan demikian, status tindak lanjutnya adalah implementasi dengan sedikit revisi dari catatan ahli karena pada rentang persentase $75 \%$ hingga $84 \%$. Berdasarkan hal tersebut terdapat komentar dari ahli puisi berkaitan dengan keefektifan penugasan siswa dan kecermatan penggunaan bahasa di dalam strategi pembelajaran. Penilaian tahap kedua yakni mendapatkan persentase kelayakan sebesar 92\%. Dengan demikian, status tindak lanjutnya adalah sangat layak karena berada dalam rentang persentase $85 \%$ hingga $100 \%$. Berkaitan dengan hal tersebut maka statusnya adalah implementasi.

Aspek kedua yang dinilai adalah akurasi strategi jurnalisme sejarah dalam pembelajaran menulis puisi. Subaspek pada penilaian pertama tersebut memperoleh persentase kelayakan $80 \%$. Dengan demikian, status tindak lanjutnya adalah implementasi dengan sedikit revisi dari catatan ahli. Berdasarkan hal tersebut terdapat catatan komentar dari ahli pembelajaran puisi terkait dengan pengubahan judul yang menarik dari tahapan pembelajaran strategi jurnalisme sejarah. Pada penilaian tahap kedua mendapatkan persentase kelayakan 92,5\%. Dengan demikian, status tindak lanjutnya adalah implementasi karena berada pada rentang persentase $85-100 \%$. Hal tersebut didukung dengan catatan komentar dari praktisi yang menyatakan bahwa strategi jurnalisme sejarah dalam menulis puisi menarik dan siswa antusias karena mendapatkan pengalaman belajar dengan metode berbeda yakni dengan melakukan pengamatan ke suatu tempat bersejarah yang terdapat sumber peninggalannya sehingga siswa dapat memaknai dan mengetahui sejarahnya secara langsung dari narasumber terpercaya dan sesuai dengan kearifan lokal setempat.

Hasil data keseluruhan diperoleh persentase kelayakan $91 \%$ yang berarti layak diimplementasikan karena pada rentang $85 \%$ hingga $100 \%$. Ketiga validator penilaian meliputi (1) ahli pembelajaran puisi memperoleh nilai rata-rata persentase $94,2 \%$, (2) ahli puisi memperoleh nilai rata-rata persentase $90,9 \%$, dan (3) praktisi bahasa Indonesia memperoleh nilai rata-rata persentasi kelayakan $88,14 \%$. Berdasarkan hasil persentase keseluruhan dapat disimpulkan bahwa produk strategi jurnalisme sejarah untuk pembelajaran menulis puisi memenuhi kualifikasi layak untuk diimplementasikan.

\section{Implementasi Strategi Jurnalisme Sejarah dalam Pembelajaran Menulis Puisi}

Hasil implementasi strategi jurnalisme sejarah pada uji coba lapangan meliputi tiga hal yaitu (1) tahap mencari topik, (2) tahap mengolah data, dan (3) tahap menyunting data. Hasil belajar dari implementasi strategi jurnalisme yakni pemilihan alur yang didasarkan pada minat dan ketertarikan siswa pada setiap fakta-fakta dari peristiwa sejarah. Alur yang dipilih oleh siswa terdapat dua pilihan yakni, alur yang dipilih secara utuh yakni meliputi keseluruhan teks narasi sejarah yang telah ditulis. Alur tersebut meliputi pendahuluan yang berisi fakta-fakta tentang topik sejarah apa yang dibahas, lokasi suatu sejarah, akses jalan yang ditempuh menuju lokasi. Inti narasi berisi tentang ciri khas dari suatu sejarah, peninggalan yang terdapat dari sisa peradaban, pengetahuan perkembangan sejarah, tokoh-tokoh penting yang terlibat, pengaruh tokoh-tokoh tersebut bagi perkembangan suatu sejarah dan pengaruh situs bagi masyarakat saat ini. Pada inti kedua yakni berisi tentang upaya pemerintah dalam mengelola situs, perkembangan dalam mengelola situs, banyaknya wisatawan untuk berkunjung, daya tarik situs yang menjadi ciri khas dan kemenarikan sendiri bagi pengunjung, serta potensi-potensi suatu sejarah agar dijadikan suatu cagar budaya didaerah.

Setelah siswa memilih narasi berdasarkan plot, selanjutnya siswa memaknai setiap unsur yang hadir pada setiap pilahan peristiwa berdasarkan plot. Pada implementasinya siswa memaknai pilahan plot tersebut dengan mendeskripsikan hasil refleksi dari setiap unsur yang hadir pada pilahan peristiwa yang meliputi kesan yang ditangkap siswa dari peristiwa sejarah, gambaran-gambaran sosok atau tokoh penting dibalik peristiwa sejarah maupun unsur yang bersifat metafisik yakni berupa nilai 
atau pelajaran yang dapat dirumuskan dari peristiwa sejarah. Selanjutnya, siswa mengimajinasikan peristiwa sejarah sebagai kesatuan peristiwa yang bersifat simbolis dari setiap hasil deskripsi refleksi. Kegiatan belajar berlanjut pada pengumpulan diksi dari setiap pengimajinasian yang dilakukan. Siswa memilih diksi puitis dari hasil pengimajinasian dengan mengindentifikasi, mengasosiasi kata puitis yang sesuai hasil refleksi dengan melibatkan pikiran, perasaan, dan penghayatan. Siswa menghindari kata-kata yang biasa digunakan sehari-hari atau kata yang bermakna lugas dan formal. Kemudian siswa mengembangkan diksi menjadi larik-larik. Pada proses tersebut, siswa belajar untuk merangkai diksi-diksi yang telah dikumpulkan dengan membentuk kalimat atau larik yang indah dan memiliki makna. Larik-larik yang bermakna merupakan larik yang ditulis berdasarkan kesatuan ide cerita atau tema dan dirangkai dengan bahasa yang menarik. Selanjutnya siswa merangkai larik-larik puisi dalam kesatuan yang membentuk bait-bait sehingga tampak lebih padat dan bermakna. Pada proses tersebut, siswa harus tetap memperhatikan kesinambungan antar larik dan menulisnya dengan melibatkan perenungan, perasaan dan penghayatan. Pada hasil uji coba lapangan terbatas tahap penulisan puisi. Dapat dirumuskan bahwa siswa memilih narasi berdasarkan plot atau alur pengisahan meliputi alur keseluruhan yang terdapat fakta dari objek situs situs sejarah, eksplorasi pengetahuan sejarah, dan eksplorasi pengetahuan pengelolaan situs sejarah. Alur sebagian yang terdapat masing-masing dari fakta yakni fakta objek situs sejarah, fakta pengetahuan sejarah situs sejarah, dan fakta pengetahuan pengelolaan situs sejarah. Dan alur sebagian yang terdapat gabungan dari dua kategori fakta terkait, yakni fakta objek dan pengetahuan sejarah, fakta objek dan hasil refleksi pada penutupan narasi, dan fakta pengetahuan sejarah dan refleksi. Hasil identifikasi tersebut juga didasarkan pada diksi, larik dan bait pada puisi yang mencerminkan kategori alur yang dipilih oleh siswa. Berikut merupakan hasil draft puisi siswa dari dua kategori alur.

Tabel 2. Pemilihan Alur dan Hasil Draft Puisi

\begin{tabular}{|c|c|c|}
\hline Pemilihan Alur & Jenis Alur & Hasil Draft Puisi \\
\hline Alur utuh & $\begin{array}{l}\text { Fakta objek situs sejarah, pengetahuan sejarah dari situs sejarah, } \\
\text { pengetahuan pengelolaan situs sejarah }\end{array}$ & $\begin{array}{l}\text { Kepergian Para Wali } \\
\text { Senja pilu } \\
\text { Menemaniku menyusuri ratusan tangga } \\
\text { jejak kisahmu } \\
\text { Membuai hari kian membiru } \\
\text { Langit-langit tampak keruh } \\
\text { Mengantar lantunan do'a do'aku } \\
\quad \text { Gerimis jatuh kian deras membasahi } \\
\text { Melagukan nada-nada suci dalam } \\
\text { hati } \\
\quad \text { Sosok pembawa rahmat semesta } \\
\quad \text { Sosok pendiri kuasa beberapa abad } \\
\quad \text { lalu } \\
\text { Telah tenang disisi-NYA } \\
\text { Kaulah panutanku } \\
\text { Hingga saat ku berdiri di puncak Giri } \\
\text { Ku mengenang dengan hikmat kisahmu } \\
\text { Oleh sosok tua pengagummu } \\
\quad \text { Kepergianmu } \\
\text { Menyisakan rindu } \\
\text { Namun... } \\
\text { Aku mengerti engkau } \\
\text { Tak layu dalam hati } \\
\text { (PPGC12) }\end{array}$ \\
\hline \multirow[t]{2}{*}{ Alur Sebagian } & Fakta objek situs sejarah & $\begin{array}{l}\text { Kerajaan Gunung } \\
\text { Menjulang tinggi } \\
\text { Menyinari peradaban Islam tanah Jawa } \\
\text { Bagai mengembara lembah } \\
\text { Menuju titik puncak } \\
\text { Tetesan peluh bercucuran } \\
\text { Mendampingiku hingga puncak } \\
\text { Puncak simbol kejayaan Islam } \\
\text { (PPIZ14) }\end{array}$ \\
\hline & Fakta pengetahuan sejarah dari situs sejarah & $\begin{array}{l}\text { Tapak Tilasmu } \\
\text { Giri Kedaton kau adalah } \\
\text { Bangunan bersejarah } \\
\text { Saksi bisu Raden Paku memaku } \\
\text { Megah sungguh bersemayam di } \\
\text { atas bukit } \\
\text { Tanah menjulang tinggi }\end{array}$ \\
\hline
\end{tabular}




\begin{tabular}{|c|c|c|}
\hline & & $\begin{array}{l}\text { Kian indah mempesona hati } \\
\text { (PPMM23) }\end{array}$ \\
\hline & \multirow[t]{12}{*}{ Fakta pengetahuan pengelolaan situs sejarah } & Terlupakan \\
\hline & & Penguasa seakan-akan membisu \\
\hline & & Tak terdengar suara bising sedikitpun \\
\hline & & Engkau kini menyendiri \\
\hline & & Diantara panasnya siang \\
\hline & & Dan dinginnya malam \\
\hline & & Engkau kini usang \\
\hline & & Termakan usia \\
\hline & & Tubuhmu yang \\
\hline & & menjulang tinggi \\
\hline & & Hanya untuk kesenangan \\
\hline & & $\begin{array}{l}\text { Mata manusia dengan berfoto ria } \\
\text { (PPHN13) }\end{array}$ \\
\hline \multirow{42}{*}{$\begin{array}{l}\text { Alur sebagian (gabungan } \\
\text { dua alur) }\end{array}$} & \multirow[t]{12}{*}{ Fakta objek dan pengetahuan sejarah } & Giri Kedaton \\
\hline & & Situs terbaik di tanah Kedaton \\
\hline & & Kau bagaikan istana \\
\hline & & Megah tepat dibawah awan \\
\hline & & Medan tempuh tingi menjulang \\
\hline & & Seolah mengantarkanku \\
\hline & & kesurga dunia \\
\hline & & Ratusan anak tangga \\
\hline & & Kupijak dengan peluh \\
\hline & & keringat menets \\
\hline & & Terbayar dengan pesona indahmu \\
\hline & & (PPLN15) \\
\hline & \multirow[t]{15}{*}{ Fakta objek dan hasil refleksi pada penutupan narasi } & Giri Kedaton \\
\hline & & Kau begitu megah dan indah \\
\hline & & $\begin{array}{l}\text { Ketinggianmu amatlah menjulang } \\
\text { bagai istana }\end{array}$ \\
\hline & & Aku menyusuri ratusan anak tangga \\
\hline & & yang terjal \\
\hline & & Setapak demi setapak \\
\hline & & Peluh lelah kurasa \\
\hline & & Disaat sudah dipuncak \\
\hline & & Sungguh indah \\
\hline & & pemandanganmu \\
\hline & & Ohh.... Giri Kedaton \\
\hline & & Kau cahaya yang bersinar \\
\hline & & Diantara kegelapan \\
\hline & & Sayangnya.... \\
\hline & & $\begin{array}{l}\text { Kaum milenial acuh terhadapmu. } \\
\text { (PPMS28) }\end{array}$ \\
\hline & \multirow{15}{*}{ Fakta pengetahuan sejarah dan refleksi } & Keagungan Sang Pelita \\
\hline & & Engkau bagai puncak himalaya \\
\hline & & Tinggi menembus angkasa \\
\hline & & Sang tumpuan menuju puncak \\
\hline & & Menyambut kehadiranku \\
\hline & & Bangunan pemersatu \\
\hline & & umat muslim \\
\hline & & Melalui sang pelita \\
\hline & & Menuju tanah Jawa \\
\hline & & Syiar kalam penuh ilmu \\
\hline & & agama \\
\hline & & Engkau saksi bisu \\
\hline & & Perjuangan sang pelita \\
\hline & & Hargai situs \\
\hline & & Agar tak pupus oleh zaman \\
\hline
\end{tabular}


Pada aktivitas belajar menyunting puisi dengan koreksi dan revisi siswa belajar memperkaya aspek citraan, majas dan harmonisasi agar puisi yang dihasilkan menjadi lebih indah dan bermakna. Untuk dapat melakukan kegiatan tersebut, siswa harus melewati proses kreatif terlebih dahulu karena hal tersebut merupakan syarat untuk menulis puisi dengan baik. Puisi yang dihasilkan siswa dibaca kembali dengan seksama. Setelah membaca puisi, siswa menghilangkan, menambah atau mengubah diksi atau larik yang dianggap tidak sesuai dengan kesatuan makna. Dalam hal ini jika memang tidak terdapat diksi atau larik yang dianggap siswa tidak memenuhi syarat tersebut maka siswa boleh untuk tidak menghilangkan diksi atau larik. Akan tetapi, siswa dapat memilih pilihan untuk menambah diksi atau larik yang tidak sesuai dengan makna dan ide penulisan.

Dalam memperkaya aspek citraan, majas dan harmonisasi bunyi. Siswa dapat mengubah diksi atau larik dengan aspekaspek tersebut. Pada tahap ini siswa memerlukan pemahaman tentang unsur kebahasaan secara jelas. Oleh karena itu, guru memberikan contoh dari masing-masing aspek kebahasaan dalam diskusi klasikal dengan contoh yang berbeda-beda dan bervariasi serta disesuaikan dengan alur pengisahan dari tahap awal aktivitas pembelajaran. Hal tersebut dilakukan agar siswa memahami dan dapat menerapkan dengan baik dari setiap proses belajar. Hasil belajar pada aktivitas belajar menyunting draft puisi adalah puisi yang telah disempurnakan dan diberikan judul yang sesuai dengan isi puisi. Berikut adalah salah satu contoh kutipan hasil dari belajar siswa berupa draft puisi hasil koreksi dan revisi.

Tabel 3. Cuplikan Hasil Karya Puisi Sebelum dan Sesudah Revisi

\begin{tabular}{|c|c|}
\hline Karya Puisi Sebelum Revisi & Karya Puisi Setelah Revisi \\
\hline $\begin{array}{l}\text { Karya } 1 \\
\text { Kepergian Para Wali }\end{array}$ & $\begin{array}{l}\text { Karya } 1 \\
\text { Kepergian Para Wali }\end{array}$ \\
\hline $\begin{array}{l}\text { Senja pilu } \\
\text { Menemaniku menyusuri ratusan tangga jejak kisahmu } \\
\text { Membuai hari kian membiru } \\
\text { Langit-langit tampak keruh } \\
\text { Mengantar lantunan do'a do'aku }\end{array}$ & $\begin{array}{l}\text { Senja pilu } \\
\text { Menemaniku menyusuri ratusan tangga jejak kisahmu } \\
\text { Membuai hari kian membiru } \\
\text { Langit-langit tampak keruh } \\
\text { Mengantar lantunan do'aku }\end{array}$ \\
\hline $\begin{array}{l}\text { Gerimis jatuh kian deras membasahi } \\
\text { Melagukan nada-nada suci dalam hati } \\
\text { Sosok pembawa rahmat semesta } \\
\text { Sosok pendiri kuasa beberapa abad lalu } \\
\text { Telah tenang disisi-NYA }\end{array}$ & $\begin{array}{l}\text { Gerimis jatuh kian deras membasahi pucuk sunyi } \\
\text { Melagukan nada-nada suci dalam hati } \\
\text { Sosok pembawa rahmat semesta } \\
\text { Sosok pendiri kuasa beberapa abad lalu } \\
\text { Telah tenang dipeluk maestro jagad raya }\end{array}$ \\
\hline $\begin{array}{l}\text { Kaulah panutanku } \\
\text { Hingga saat ku berdiri di puncak Giri } \\
\text { Ku mengenang dengan hikmat kisahmu } \\
\text { Oleh sosok tua pengagummu }\end{array}$ & $\begin{array}{l}\text { Kaulah panutanku } \\
\text { Hingga saat ku berdiri di puncak Giri } \\
\text { Ku mengenang dengan hikmat kisahmu } \\
\text { Oleh sosok tua pengagummu }\end{array}$ \\
\hline $\begin{array}{l}\text { Kepergianmu } \\
\text { Menyisakan rindu }\end{array}$ & $\begin{array}{l}\text { Kepergianmu } \\
\text { Membuat bagai kota mati }\end{array}$ \\
\hline $\begin{array}{l}\text { Namun.... } \\
\text { Aku mengerti engkau } \\
\text { Tak layu dalam hati } \\
\text { (PPGC12) }\end{array}$ & $\begin{array}{l}\text { Namun.... } \\
\text { Aku mengerti engkau } \\
\text { Tak layu dalam hati } \\
\text { (PPGC12) }\end{array}$ \\
\hline
\end{tabular}

Berdasarkan puisi karya PPGC12 diketahui bahwa puisi karya siswa memilih alur yang mencakup pendahuluan, inti, penutup (refleksi) berdasarkan fakta utuh atau fakta-fakta yang mencakup data secara keseluruhan. Hal tersebut tampak pada bait pertama yang menjelaskan tentang penampakan situs sejarah yang memiliki ratusan anak tangga. Hal tersebut terdapat pada teks narasi sejarah yang menjelaskan bahwa sebelum sampai wilayah situs harus melewati ratusan anak tangga terlebih dahulu. Kemudian pada bait kedua menjelaskan tentang sosok Sunan Giri sebagai pendiri situs tersebut yang memiliki jasa luar biasa bagi dalam menyebarkan agama Islam dan membawa kedamaian. Hal tersebut terdapat pada fakta pengetahuan sejarah situs yang didalamnya membahas tentang sosok Sunan Giri.

Pada bait ketiga menjelaskan bahwa sosok Sunan Giri adalah sosok panutan bagi penulis dan dikisahnya lengkap diceritakan oleh juru pelihara Giri Kedaton yakni dibuktikan dengan larik / Ku mengenang dengan hikmat kisahmu

Oleh sosok tua pengagummu/ diksi /Sosok tua/ menggambarkan tentang bapak mukhtar yang usianya 65 tahun sebagai juru pelihara situs dan beliau juga sangat mengagumi dan menjadikan para wali sebagai panutan. Mengenai juru pelihara sebagai orang yang memelihara dan menjaga kebersihan situs terdapat pada fakta pengelolaan situs sejarah.

Pada bait kelima menjelaskan tentang refleksi penulis dalam memaknai peristiwa sejarah. Hal tersebut dibuktikan dengan larik / Aku mengerti engkau tak layu dalam hati/ yang memiliki makna bahwa Sunan Giri dan Giri Kedaton tidak akan dilupakan oleh manusia yang menghargai peninggalan beliau dan selalu mengenang beliau. 
Hasil koreksi dan revisi tampak pada penghilangan diksi /do'aku/ pada bait pertama larik kelima. Penambahan diksi /Pucuk sunyi/ pada bait kedua larik pertama, diksi tersebut merupakan majas yang menambah keindahan larik. Pengubahan diksi /Disisi-Nya/ menjadi larik /dipeluk maestro jagad raya/ yang merupakan majas metafora yakni menggambarkan Tuhan seperti maestro yakni orang yang ahli dalam bidang seni namun diperjelas dengan jagad raya yang memiliki makna bahwa Tuhan yang memiliki ahli dalam menciptakan jagad raya dengan seni yang indah.

Pada bait keempat yakni /Menyisakan rindu/ diganti dengan /Membuat bagai kota mati/. Larik tersebut merupakan majas perumpamaan /simile yang menyamakan kepergian dari Sunan Giri seperti kota yang mati tak berpenghuni dan kosong. Harmonisasi bunyi tampak pada bait pertama yakni pada diksi /Pilu/Kisahmu/Membiru/Keruh/Do'aku/.

\section{Kelayakan Uji Efektivitas Data}

Keefektifan strategi jurnalisme sejarah dalam pembelajaran dibuktikan melalui uji efektifitas data dengan data deskriptif, uji normalitas, uji homogenitas dan uji T. Nilai hasil pretest dan posttest menjadi acuan dalam mengolah data (Effendy, 2016). Nilai hasil pretest merupakan nilai hasil pembelajaran menulis puisi sebelum diberi perlakuan khusus dan nilai posttest merupakan nilai hasil pembelajaran puisi setelah diterapkan strategi jurnalisme sejarah. Data yang diperoleh dari hasil data deskriptif yakni pretes eksperimen yang berjumlah 34 siswa memperoleh nilai minimum 64, nilai maksimum 80, nilai ratarata 73,06 dan standar deviasi 4.067 pada pembelajaran menulis puisi dengan metode konvensional atau tanpa diberi perlakuan strategi tertentu. Sedangkan pada postes yakni setelah diberikan perlakuan strategi jurnalisme sejarah pada pembelajaran menulis puisi memperoleh nilai minimum 65, nilai maksimum 64, nilai rata-rata 78,06, dan standar deviasinya 5.320.

Pada uji normalitas nilai signifikansi (sig) pada pretest adalah 0,066 yakni lebih besar dari 0,05 maka dapat disimpulkan bahwa populasi data berdistribusi normal. Selanjutnya uji homogenitas memperoleh nilai signifikansi (sig) berdasarkan nilai rata-rata adalah 0,0851 > 0,05, sehingga dapat disimpulkan bahwa varian data posttest kelas eksperimen adalah sama atau homogen dan terakhir uji T diperoleh nilai signifikan (2-tailed) sebesar 0,000<0,05 maka dapat disimpulkan bahwa ada pengaruh strategi jurnalisme sejarah dalam menulis puisi terhadap hasil belajar siswa pada mata pelajaran Bahasa Indonesia materi menulis puisi

\section{Revisi Produk pada Kelayakan Konsep Strategi Jurnalisme Sejarah}

Pada aspek kelayakan konsep strategi jurnalisme sejarah, ahli pembelajaran puisi dan ahli puisi memberikan pendapat berupa komentar dan saran yang serupa terhadap teknik penyajian konsep dasar, contoh penerapan penyajian langkah-langkah dalam buku panduan strategi jurnalisme sejarah untuk pembelajaran menulis puisi. Kedua ahli menyebutkan bahwa penyajian meliputi konsep dasar strategi jurnalisme sejarah yang meliputi pengantar, landasan pengembangan, tahapan pembelajaran dan contoh penerapan pada aktivitas belajar siswa masih belum sistematis dan keefektifan penggunaan bahasa dalam sajian aktivitas belajar siswa perlu dicermati kembali sehingga isi dari pembelajaran menjadi tumpang tindih. Oleh karena itu, perlu diklasifikasi ulang. Berdasarkan pendapat tersebut, perbaikan yang dilakukan pada buku panduan strategi adalah menata ulang sajian substansi dari konsep dasar strategi sesuai dengan pendapat dari kedua ahli. Perbaikan juga termasuk pada isi dari landasan pengembangan yakni menghilangkan kriteria mengenai prinsip-prinsip jurnalis secara profesional yang kemudian diganti dan dilengkapi dengan sajian tugas-tugas jurnalis secara umum dan tahapan panduan wawancara.

\section{Revisi Produk pada Kelayakan Langkah-Langkah Strategi jurnalisme Sejarah untuk Pembelajaran Menulis Puisi}

Pada aspek kelayakan langkah-langkah strategi jurnalisme sejarah untuk pembelajaran menulis puisi, ahli pembelajaran puisi memberikan pendapat mengenai penugasan yang terdapat pada setiap tahapan tugas jurnalis kurang operasional dan contoh puisi dengan tema sejarah kurang bervariasi dan terdapat contoh puisi sejarah yang kurang disesuaikan dengan jenjang kelas X SMA. Berdasarkan hal tersebut, pada perbaikan tahap-tahap strategi jurnalisme sejarah meliputi penugasan yang bersifat umum pada tugas jurnalis namun disertai dengan contoh pengaplikasian pada pembelajaran, menambahkan bagan diagram alir atau flowchart yang meliputi tahapan pembelajaran strategi, tabel aktivitas dan hasil belajar serta menambahkan contoh puisi sejarah yang bervariasi serta disesuaikan dengan pemahaman jenjang kelas X SMA. Berkaitan dengan pemilihan puisi sebagai materi ajar, puisi-puisi karya penyair sangat beragam jenisnya dan pemilihan puisi tersebut harus disesuaikan sebagai bahan pengajaran disekolah. Beberapa pertimbangan tersebut antara lain bahasa yang digunakan, tinjauan dari segi kejiwaan, tinjauan dari segi pendidikan, tinjauan dari segi keindahan (Suwardo, 2009). Apabila kesenjangan tersebut tidak diatasi dengan menambahkan aktivitas belajar dan menyertakan contoh yang lebih konkret, siswa tidak mampu berproses kreatif sesuai dengan apa yang diharapkan guru dan tujuan pembelajaran. Hal tersebut sesuai dengan pernyataan Wommelsduff (2005) bahwa proses kreatif dalam diri siswa tidak akan berjalan dengan optimal jika guru memberikan kebebasan tak terbatas dalam proses menulis puisi.

\section{Revisi Produk pada Kelayakan Strategi Jurnalisme Sejarah terhadap Tingkat Pemahaman dan Kebutuhan Siswa}

Pada aspek kelayakan strategi jurnalisme sejarah terhadap tingkat pemahaman dan kebutuhan siswa ahli puisi berpendapat mengenai penugasan yang terkait dengan lembar kerja siswa dan materi pembelajaran. Pada lembar kerja siswa penugasan kurang sistematis, penggunaan bahasa kurang efektif, dan urutan pembelajaran kurang operasional. Oleh sebab itu, 
produk yang direvisi berkaitan dengan pengorganisasian tata urutan penugasan siswa, penggunaan bahasa yang digunakan disesuaikan dengan perkembangan kognitif, menggunakan struktur kalimat dan kata-kata yang jelas. Sedangkan pada materi pembelajaran yakni contoh puisi-puisi sejarah kurang bervariasi. Oleh sebab itu, produk yang direvisi berkaitan penambahan contoh puisi sejarah karya penyair Indonesia.

\section{Revisi Produk Berdasarkan Hasil Uji Lapangan Terbatas}

Berdasarkan persentase kelayakan strategi jurnalisme sejarah telah memenuhi kriteria kelayakan karena perhitungan keseluruhan jawaban siswa memperoleh 92,6\%. Oleh karena itu, strategi jurnalisme sejarah tergolong sebagai produk yang layak diimplementasikan. Selain berdasarkan keseluruhan perhitungan angket siswa dengan persentase, tingkat kelayakan strategi jurnalisme sejarah juga memperoleh respons positif dari peserta didik berupa komentar yang menyatakan beberapa hal terkait dengan pembelajaran, yaitu (1) setelah mengikuti pembelajaran menulis puisi dengan praktik jurnalis siswa menjadi lebih antusias dan mendapat pengalaman baru yang berbeda, (2) siswa menjadi lebih tertarik menulis puisi sejarah karena dengan metode yang diterapkan pada pembelajaran, (3) siswa lebih mengetahui dan memaknai peristiwa sejarah yang terdapat didaerah mereka dan menuangkan hasil pengamatan dalam bentuk puisi, (4) siswa mengetahui bagaimana proses pengimajinasian dari hasil deskripsi refleksi peristiwa sejarah, (5) siswa menjadi lebih mudah menulis puisi dengan pengalaman belajar berbeda. Tidak hanya didalam kelas dengan media audiovisual, namun juga belajar di luar kelas, dan (6) siswa mudah mengerti dan memahami cara mengolah data hingga tahap akhir menyunting hasil puisi.

Berdasarkan fakta penerapan strategi jurnalisme sejarah di lapangan, hal yang perlu dipertimbangkan adalah waktu pelaksanaan pembelajaran. Hal tersebut juga disampaikan oleh praktisi yang menyampaikan bahwa alokasi waktu dalam pembelajaran perlu diperhatikan agar tahap-tahap dari aktivitas belajar di dalam strategi dapat dicapai dengan maksimal. Oleh karena itu terdapat saran dari praktisi mengenai pembagian waktu dalam pelaksanaan pembelajaran menulis puisi dengan menerapkan strategi jurnalisme sejarah yakni dengan mengorganisasi waktu paling sedikit empat kali empat puluh menit dengan pembagian waktu (1) satu kali empat puluh menit untuk melaksanakan tahap mencari data yang didalamnya terdapat aktivitas belajar praktik wawancara dengan narasumber untuk mengumpulkan informasi berupa fakta-fakta, (2) dua kali dua puluh menit untuk melaksanakan tahap mengolah data dengan menulis narasi sejarah berdasarkan data-data yang telah dikumpulkan yakni hasil jawaban narasumber yang dikembangkan menjadi narasi dan (3) satu kali empat puluh menit untuk melaksanakan tahap menyunting data yakni aktivitas menulis puisi dan menyunting hasil draft puisi dengan memperkaya aspek unsur kebahasaan puisi. Oleh karena itu, efisiensi penyajian langkah-langkah belajar serta kecepatan siswa menjadi hal penting untuk dipertimbangkan.

Selain hal tersebut, faktor-faktor pendukung lainnya juga berpengaruh terhadap kelancaran pelaksanaan strategi jurnalisme sejarah, hal tersebut meliputi (1) kenyamanan suasana belajar di dalam kelas dan keamanan saat praktik jurnalis di lapangan menjadi faktor penting agar kelangsungan proses belajar menjadi maksimal, (2) ketersediaan sarana pembelajaran yang mendukung penerapan strategi jurnalisme sejarah. Dalam pelaksanaan strategi jurnalisme sejarah dalam menulis puisi terdapat penggunaan media pembelajaran yang bersifat audio visual. Akan tetapi, jika hal tersebut tidak tersedia dalam fasilitas sekolah, guru dapat menyesuaikannya dengan sarana yang ada serta dapat mengimprovisasikan hal-hal terkait penggunaan media dengan sarana yang memungkinkan untuk digunakan. Hal tersebut sesuai dengan pernyataan (Miner, Bassoff, \& Moorman, 2001) Secara khusus, dalam pembelajaran improvisasi, pengalaman dan perubahan terkait terjadi pada saat yang sama. Kami kemudian melaporkan temuan empiris yang mengungkapkan bagaimana improvisasi dapat memengaruhi pembelajaran dan adaptasi organisasi jangka panjang. Berdasarkan fakta-fakta tersebut maka dalam sajian terevisi ditambahkan faktor-faktor pendukung dalam penerapan strategi jurnalisme sejarah berupa pembangunan suasana belajar serta saranaprasarana yang mendukung.

\section{SIMPULAN}

Strategi jurnalisme sejarah adalah strategi pembelajaran yang dikembangkan untuk kompetensi menulis puisi pada jenjang kelas X SMA. Strategi jurnalisme sejarah dikembangkan berdasarkan tiga landasan penting yakni, (1) terinspirasi dari tugas jurnalis secara umum dalam mengolah informasi, (2) sumber, bukti dan fakta dalam sejarah yang membahas mengenai kriteria dari suatu sejarah yang dapat ditelusuri informasinya dan, (3) proses kreatif dalam menulis puisi.

Langkah-langkah pembelajaran dalam strategi jurnalisme sejarah dalam menulis puisi, yaitu (1) tahap mencari topik, (2) tahap mengolah data, dan (3) tahap menyunting data. Hasil dari penelitian pengembangan, meliputi (1) buku panduan model strategi jurnalisme sejarah untuk pembelajaran menulis puisi yang memuat konsep dasar, langkah-langkah pembelajaran, implementasi dalam setiap tahapan pembelajaran dalam bentuk penugasan, contoh hasil aktivitas di setiap langkah-langkah pembelajaran, rencana pelaksanaan pembelajaran, rubrik penilaian serta lembar kerja siswa. Semua komponen diorganisasikan dengan baik, sistematis dan teratur sehingga guru sebagai pengguna buku panduan dapat memahami esensi dari isi, penyajian dari setiap pembelajaran dan aktivitas belajar. Dalam hal media dan materi pembelajaran tertuang dalam strategi jurnalisme sejarah sehingga penerapan strategi dapat lebih optimal dan terlaksana dengan baik. (2) kelayakan produk oleh ahli dan praktisi yang terdiri dari tiga aspek, yakni (1) konsep strategi jurnalisme sejarah, (2) langkah-langkah strategi jurnalisme sejarah dalam pembelajaran menulis puisi, dan (3) kelayakan strategi jurnalisme terhadap tingkat pemahaman dan kebutuhan siswa. 
Aspek kelayakan konsep strategi jurnalisme sejarah memperoleh presentase kelayakan sebesar 88,9\% dari para ahli dan praktisi. Berdasarkan hal tersebut maka berstatus layak diimplementasikan. Berdasarkan angket uji validasi, ahli pembelajaran puisi dan puisi memberikan saran yang serupa mengenai sajian isi buku panduan yang meliputi penataan ulang dari pengantar, konsep strategi, tahapan strategi, implementasi pada proses pembelajaran, dan mencermati dari segi keefektifan bahasa dan kerapatan pengetikan sehingga akan lebih sistematis dan jelas bahwa buku panduan ditujukan untuk guru. Oleh karena itu, sajian tersebut perlu diorganisasikan ulang. Hasil pengorganisasian ulang dari produk buku panduan strategi jurnalisme sejarah menghasilkan sajian lima bab, yaitu bab pertama konsep dasar strategi jurnalisme sejarah berisi enam subfokus meliputi (1) landasan strategi jurnalisme sejarah, (2) strategi jurnalisme sejarah, (3) karakteristik jurnalisme sejarah, (4) keunggulan dan kelemahan strategi jurnalisme sejarah, (5) konsep dasar puisi sejarah, dan (6) mengenal puisi sejarah. Bab kedua tahapan strategi jurnalisme sejarah berisi lima subfokus meliputi (1) mencari topik, (2) mengolah data, (3) mengolah data, (4) alur strategi jurnalisme sejarah, dan (5) tabel tahapan strategi jurnalisme sejarah. Bab ketiga implementasi strategi jurnalisme sejarah dalam menulis puisi berisi tiga subfokus meliputi (1) mencari topik, (2) mengolah data, dan (3) menyunting data. Bab keempat perangkat pembelajaran berisi dua subfokus meliputi (1) rencana pelaksanaan pembelajaran, dan (2) rubrik penilaian. Bab kelima berisi dua subfokus meliputi (1) kesimpulan, dan (2) saran.

Aspek kelayakan langkah-langkah strategi jurnalisme sejarah dalam pembelajaran menulis puisi mendapatkan presentase kelayakan sebesar 90,6\% dari para ahli dan praktisi. Berdasarkan hal tersebut maka berstatus layak untuk diimplementasikan. Meskipun demikian, ahli pembelajaran puisi memberikan pendapat untuk kepentingan perbaikan produk. Pendapat tersebut meliputi penugasan yang terdapat pada setiap tahapan tugas jurnalis kurang operasional, contoh puisi dengan tema sejarah kurang bervariasi dan terdapat contoh puisi sejarah yang kurang disesuaikan dengan jenjang kelas X SMA. Berdasarkan pendapat tersebut maka perbaikan yang dilakukan meliputi tiga hal. Pertama, mengoperasionalkan setiap tahapan jurnalis yang disesuaikan dengan tahapan jurnalis secara umum. Hal tersebut dilakukan karena sumber inspirasi strategi berdasarkan tahapan jurnalis namun disesuaikan dengan pembelajaran sehingga tahapan jurnalis secara profesional berbeda dengan tahapan jurnalis yang diintegrasikan dalam pembelajaran menulis puisi. Tahapan jurnalis secara umum yang disesuaikan dengan pembelajaran adalah tahap mencari topik, mengolah data dan menyunting data. Kedua, keseluruhan tahapan jurnalis diwujudkan dalam bentuk diagram alir atau flowchart. Tujuan dari diagram alir adalah untuk menjelaskan keseluruhan dari tahapan jurnalis dalam strategi jurnalisme sejarah dengan diagram yang mewakili ilustrasi atau langkah-langkah dalam bentuk simbol grafis yang urutan-urutannya dihubungkan dengan anak panah sehingga guru sebagai sasaran pengguna dari buku panduan mendapatkan pemahaman dengan jelas dan singkat. Ketiga, membuat tabel strategi jurnalisme sejarah berdasarkan tahapan strategi, aktivitas belajar, hasil belajar dan sumber belajar. Hal tersebut dilakukan bertujuan untuk mengklasifikasikan secara rinci keseluruhan dari inti produk buku panduan tersebut dan diwujudkan dalam bentuk tabel. Keempat, pada produk sajian implementasi strategi jurnalisme sejarah contoh puisi tema sejarah yang pada awalnya cuplikan tayangan pembacaan puisi berjudul "Dibawah Selimut Kedamaian Palsu" karya Wiji Thukul menjadi puisi berjudul "Krawang-Bekasi" karya Chairil Anwar, dan penataan kerapatan pengetikan serta keefektifan bahasa dalam penugasan. Media audio visual dalam bentuk tayangan video tersebut digunakan untuk menstimulus siswa dalam pemahaman mengenai contoh puisi sejarah yang dibahas mengenai isi dan pesan yang disampaikan pengarang kepada pembaca melalui tayangan pembacaan puisi. Pemanfaatan media pembelajaran pada akhirnya membentuk penciptaan kondisi belajar yaitu pemahaman peristiwa sejarah yang terdapat pada puisi untuk mencapai kompetensi dasar yang dituju, yaitu menulis kreatif puisi yang berpusat pada siswa (Sukirno, 2009).

Aspek kelayakan strategi jurnalisme terhadap tingkat pemahaman dan kebutuhan siswa memperoleh presentase kelayakan sebesar 92,2\%. Berdasarkan hal tersebut bersatatus layak diimplementasikan. Akan tetapi, ahli pembelajaran puisi dan ahli puisi memberikan pendapat terhadap perbaikan produk. Kedua ahli tersebut memberikan pendapat yang serupa yakni keoperasionalan dalam penugasan, keefektifan bahasa yang digunakan dalam lembar kerja siswa dan kurang bervariasi dalam contoh-contoh puisi sejarah dalam materi pembelajaran. Berdasarkan pendapat tersebut hasil revisi yang dilakukan meliputi tiga hal. Pertama, mengoperasionalkan substansi dari setiap penugasan yang ditujukan kepada siswa. Hal tersebut yakni untuk memberikan penjelasan kepada guru sebagai pengguna buku panduan bahwa penugasan yang dilakukan tidak hanya dilakukan didalam kelas namun juga dilakukan diluar kelas dengan praktik jurnalis. Kedua, perbaikan keefektifan bahasa pada lembar kerja siswa. Lembar kerja siswa yang telah direvisi terdiri dari empat yakni lembar kerja mencatat pokok-pokok jawaban hasil wawancara, lembar kerja menulis teks narasi, lembar kerja mengonversi teks narasi menjadi puisi, dan lembar kerja menyunting draft puisi. Penugasan dalam bentuk lembar kerja siswa dalam setiap tahapan yakni lebih kompleks dan terdapat variasi bentuk latihan untuk menunjukkan perbedaan bentuk-bentuk latihan dan menunjukkan gradasi atau tingkatan kesulitan latihan untuk dapat meningkatkan pemahaman dan keterampilan siswa dalam mengerjakan tugas (Olinghouse 2008). Ketiga, menambahkan contoh-contoh puisi sejarah karya penyair Indonesia yakni puisi berjudul "Peringatan" karya Wiji Thukul, puisi "KrawangBekasi” karya Chairil Anwar dan puisi “Mengenang elang Mulya, Hery Hertanto, Hendriawan Lesmana dan Hafidhin Royan" karya Taufik Ismail. Ketiga contoh puisi sejarah tersebut menunjukkan bahwa terdapat latar belakang penciptaan puisi dengan tema sejarah yang berbeda. 
Puisi sejarah yang diciptakan berdasarkan pengalaman peristiwa sejarah yang dialami oleh penyair yang berarti bahwa penyair terlibat dalam peristiwa sejarah yang menjadi sesuatu yang penting pada masa tersebut serta memiliki dampak yang luar bisa dalam kehidupan. Sehingga pada masa saat ini pembaca yang membaca karya penyair tersebut dapat mengkaji peristiwa sejarah pada masa tersebut melalui diksi dan larik yang tertuang sehingga menimbulkan makna yang mendalam. Puisi sejarah yang diciptakan berdasarkan pengamatan penyair mengenai peristiwa sejarah dimasa lalu dan kemudian dituangkan dalam bentuk puisi sehingga terdapat pesan atau amanat yang ingin diungkapkan oleh penyair kepada pembaca.

Saran diberikan berdasarkan aspek diseminasi dan pengembangan lebih lanjut. Untuk saran diseminasi, upaya penyebarluasan produk dapat dilakukan melalui beberapa cara, antara lain (1) produk dapat disebarluaskan melalui kegiatankegiatan seminar akademik yang membahas tentang pembelajaran bahasa Indonesia di sekolah, (2) produk dapat disebarluaskan melalui penulisan artikel dalam jurnal pendidikan yang berbasis cetak maupun daring, (3) produk dikirimkan kepada pihak penerbitan buku untuk dicetak dan disebarluaskan dalam skala yang lebih besar, dan (4) produk disebarluaskan dalam kegiatan pelatihan untuk guru bahasa Indonesia.

Produk buku panduan Model Strategi Jurnalisme Sejarah untuk Pembelajaran Menulis Puisi masih memiliki kekurangan. Oleh karena itu, dibutuhkan pengembangan yang lebih lanjut. Terkait dengan hal tersebut, saran kepada peneliti atau pengembang yang sejenis dengan penelitian ini untuk mengkaji lebih lanjut tentang adanya kekurangan yang terdapat dalam produk Model Strategi Jurnalisme Sejarah untuk Pembelajaran Menulis Puisi sehingga produk dapat diperbaiki dan dioptimalkan dalam kegiatan pembelajaran menulis puisi yang memperhatikan segi inovasi dan kreativitas.

\section{DAFTAR RUJUKAN}

Anat, W. (2017). Towards A Model of Poetry Writing Development as A Socially Contextualised Process. Journal of Writing Research, 9(2), 127-150. https://Doi.Org/10.17239/Jowr-2017.09.02.02

Arikunto, S. (2009). Dasar-Dasar Evaluasi Pendidikan. Jakarta: Bumi Aksara.

Borg, W. R., M.D., Gall, J. P. (2003). Educational Research: An Introduction (Seventh Edition). New York: Pearson Education.

Effendy, I. (2016). Pengaruh Pemberian Pre-Test dan Post-Test terhadap Hasil Belajar Mata Diklat Hdw.Dev.100.2. A Pada Siswa SMK Negeri 2 Lubuk Basung. VOLT: Jurnal Ilmiah Pendidikan Teknik Elektro, 1(2), 81-88.

Endraswara, S. (2003b). Membaca, Menulis, Mengajarkan Sastra. Yogyakarta: Penerbit Kota Kembang.

Hasanah, M. (2014). Karakteristik Struktural-Semiotik Puisi-Puisi Karya D. Zawawi Imron. Litera, 12(2), $269-286$. https://Doi.Org/10.21831/Ltr.V12i02.1589

Hasirci, D., \& Ultav, Z. T. (2012). An Interdisciplinary Approach to The Design Studio: Poetry as A Complementary Feature to The Creative Process. Procedia - Social and Behavioral Sciences, 51, 618-634. Https://Doi.Org/10.1016/J.Sbspro.2012.08.214

Jihad, A, A., H. (2013). Evaluasi Pembelajaran. Yogyakarta: Multi Pressindo.

Khakim, M. N. L. (2016). Telaah Penulisan Karya Sastra Sejarah sebagai Refleksi Sumber Pembelajaran Sejarah. Sejarah dan Budaya: Jurnal Sejarah, Budaya, dan Pengajarannya, 10(1), 89-94. https://Doi.Org/10.17977/Um020v10i12016p089

Kuntowijoyo. (2006). Budaya dan Masyarakat. Yogyakarta: Tiara Wacana.

Linaberger, M. (2005). Poetry Top 10: A Foolproof Formula for Teaching Poetry. The Reading Teacher, 58(4), $366-372$.

Miner, A. S., Bassoff, P., \& Moorman, C. (2001). Organizational Improvisation and Learning: A Field Study. Administrative Science Quarterly, 46(2), 304. Https://Doi.Org/10.2307/2667089

Natalie Olinghouse. (2008). Designing Lessons for Diverse Learners. http://education.msu.edu/te/elementary/pdf/DesigningLessons-for-Diverse-Learners.pdf

Neroni, J., Meijs, C., Gijselaers, H. J. M., Kirschner, P. A., \& De Groot, R. H. M. (2019). Learning Strategies and Academic Performance in Distance Education. Learning and Individual Differences, 73, 1-7. Https://Doi.Org/10.1016/J.Lindif.2019.04.007

Orion, N., \& Hofstein, A. (1994). Factors That Influence Learning During a Scientific Field Trip in A Natural Environment. Journal of Research in Science Teaching, 31(10), 1097-1119. Https://Doi.Org/10.1002/Tea.3660311005

Pedersen, E. G. (2015). Symbolism, The Beginning of Modern Poetry. Procedia - Social and Behavioral Sciences, 180, 593599. Https://Doi.Org/10.1016/J.Sbspro.2015.02.165

Pratiwi, Y. D., Maryaeni., \& Suwignyo, H. (2016). Kreativitas Siswa Dalam Menulis Puisi. Jurnal Pendidikan: Teori, Penelitian, dan Pengembangan, 1(5), 835-843.

Rahman, A. (2017). Pemanfaatan Situs Sejarah sebagai Sumber Belajar di MA Alma'arif Singosari Kabupaten Malang. Skripsi tidak diterbitkan. Universitas Islam Negeri Maulana Malik Ibrahim Malang.

Roekhan. (1991). Menulis Kreatif: Dasar-Dasar dan Petunjuk Penerapannya. Malang: YA3.

Romli, A. S. M. (2003). Jurnalis Praktis. Bandung: Remaja Rosda Karya.

Rosenhan, C., \& Galloway, N. (2019). Creativity, Self-Reflection and Subversion: Poetry Writing for Global Englishes Awareness Raising. System, 84, 1-13. Https://Doi.Org/10.1016/J.System.2019.04.005

Samsudin, M. D. I. (2016). Pengaruh Pembelajaran Model Observasi Lapangan (Outdoor Study) dan Pembelajaran Inquiry terhadap Hasil Belajar Mata Pelajaran Sosiologi Siswa IPS SMA Negeri 3 Probolinggo. Jurnal Penelitian dan Pendidikan IPS, 10(2), 261-276. 
Shaw, T., \& White, C. (2004). Public Relations and Journalism Educators' Perceptions of Media Relations. Public Relations Review, 30(4), 493-502. Https://Doi.Org/10.1016/J.Pubrev.2004.08.004

Sjamsuddin, H. (2007). Metodologi Sejarah. Yogyakarta: Ombak.

Sugiyono. (2013). Metode Penelitian Pendidikan Pendekatan Kuantitatif, Kualitatif, dan R\&D. Bandung: Alfabeta.

Suhandang, K. (2004). Pengantar Jurnalistik: Seputar Organisasi, Produk, dan Kode Etik. Bandung: Penerbit Nuansa.

Sukirno. (2009). Pembelajaran Menulis Kreatif dengan Strategi Belajar Akselerasi. Purworejo: UM Purworejo Press.

Sulasman. (2014). Metodologi Penelitian Sejarah. Bandung: Pustaka Utama.

Sulistyorini, D. (2010). Peningkatan Keterampilan Menulis Puisi dengan Media Gambar pada Siswa Kelas V SDN Sawojajar V Kota Malang. J-TEQIP, 1(1), 12-19.

Suwardo. (2009). Beberapa Aspek Pengajaran Puisi di Sekolah Menengah Atas. Jurnal Ilmiah Widya Warta, 33(1), 1-13.

Tebbel, J. (2003). Karier Jurnalistik Cetakan Ketiga. Semarang: Dahara Prize.

Torralba, K. D., \& Doo, L. (2020). Active Learning Strategies to Improve Progression from Knowledge to Action. Rheumatic Disease Clinics of North America, 46(1), 1-19. Https://Doi.Org/10.1016/J.Rdc.2019.09.001

Widijanto, T. (2014). Menulis Sastra, Siapa Takut? Yogyakarta: Pustaka Puitika.

Wommelsduff, D. (2005). The Paradox of Structure and Freedom: An Experiment in Writing Poetry. The English Journal, 94(4), $23-39$. 